University of Nebraska - Lincoln

DigitalCommons@University of Nebraska - Lincoln

Journal for the Advancement of Developing

Economies

Economics Department

2016

\title{
Barriers to Prevention in Dengue Fever in Pakistan, Khyber Pakhtunkhwa, Swat District
}

\author{
Abdul Zahir \\ The University Agriculture \\ Assad Ullah \\ The University Agriculture \\ Mussawar Shah \\ The University Agriculture \\ Arsalan Mussawar \\ Ayub Medical College
}

Follow this and additional works at: https://digitalcommons.unl.edu/jade

Part of the Econometrics Commons, Growth and Development Commons, International Economics Commons, Political Economy Commons, Public Economics Commons, and the Regional Economics Commons

Zahir, Abdul; Ullah, Assad; Shah, Mussawar; and Mussawar, Arsalan, "Barriers to Prevention in Dengue Fever in Pakistan, Khyber Pakhtunkhwa, Swat District" (2016). Journal for the Advancement of Developing Economies. 11.

https://digitalcommons.unl.edu/jade/11

This Article is brought to you for free and open access by the Economics Department at DigitalCommons@University of Nebraska - Lincoln. It has been accepted for inclusion in Journal for the Advancement of Developing Economies by an authorized administrator of DigitalCommons@University of Nebraska - Lincoln. 


\title{
Barriers to Prevention in Dengue Fever in Pakistan, Khyber Pakhtunkhwa, Swat District
}

\author{
Abdul Zahir ${ }^{1}$, Asad Ullah ${ }^{1}$, Mussawar Shah ${ }^{1}$, Arsalan Mussawar ${ }^{2}$ \\ ${ }^{1}$ The University Agriculture, Peshawar-Pakistan. \\ ${ }^{2}$ Ayub Medical College, Abbottabad-Pakistan.
}

\begin{abstract}
The main aim of this study was to find out the barriers in dengue prevention in the Swat District of Khyber Pkhtunkhwa Province, Pakistan. A sample size of 354 respondents were proportionally allocated to each Mahallah or street (Tahir Abad, Angaro Dheri, Usman Abad and Banr) and then randomly selected. The association of the independent variable (barriers to prevention) and dependent variables (practices for control) were tested by using a Chi Square test. The perception about barriers in dengue prevention shows that a highly significant association was found between practices for control and access to medical facilities $(p=0.034)$, government agencies to eradicate dengue breeding sites $(p=0.005)$, dengue insecticides available in market $(p=0.028)$, use of bed nets $(p=0.000)$, government/NGO instruction $(p=0.008)$ and inconvenient sleep in bed nets $(p=0.000)$. The barriers which enhanced the susceptibility of dengue epidemic were high population density, sufficient breeding sites in residential areas, and lack of coordination of government agencies with citizens to give instruction and advices about dengue prevention and treatment. Rather than the government, most of the infected persons were advised and treated by private health clinics. The study recommends controlling dengue fever and its vectors in the most vulnerable areas by providing emergency facilities, medicines, preventive chemicals and mosquito nets free of cost or with price controls.
\end{abstract}

Keywords: Advices, Bed Nets, Dengue, Fever, Government, People Organization.

\section{INTRODUCTION}

Dengue fever is also known as break bone fever, which appears with symptoms of headaches, high temperature, muscular/bone pains and decrease of platelets (Gubler, 2010). Dengue fever is caused by a virus which has four stereotypes (DENV-1 to DENV-4) and is transmitted through female mosquitos known as Aides Aegypti. It is mostly found in urban and semi urban regions, between latitudes of $35^{\circ} \mathrm{N}$ and $35^{\circ} \mathrm{S}$. The severe conditions of dengue fever are Dengue hemorrhagic fever and Dengue Shock Syndrome (Guzman, 2002). The Dengue hemorrhagic fever has symptoms of high temperature, bleeding, low platelet counts, and plasma leakage due to low concentration of proteins and albumins in blood (Pan American Health Organization, 1994). Dengue shock syndrome occurs after 2-7 days of dengue hemorrhagic fever along with symptoms of low blood pressure and pulse, belly pain, and patient's restlessness (World Health Organization, 1997).

The Swat District, in the northern area of Khyber Pakhtunkhwa Province, was struck by dengue fever in August 2013. A total of 8,963 dengue cases and 36 deaths were registered during the 
epidemic. The DNV-1, DNV-2 and DNV-3 viruses were confirmed in patients. The blood samples of these patients were tested in Islamabad and Lahore. Besides the Swat District, the other regions of KP (Mardan, Shangla and Dir Lower) were also hit by dengue virus. The total number of dengue cases in four provinces of Pakistan as recorded in Nov 2013 were; Khyber Pakhtunkhwa, 9,321, Punjab, 1,103, Baluchistan, 15 and Sindh, 3,889 (National Institute of Health \& World Health Organization, 2013).

The dengue hemorrhagic fever may affect the human life directly and indirectly. The direct impacts include periods of illness, treatment, and monetary expenditure of patients and their parents. The indirect factors are life disturbances and psychological disorders. The measurement of indirect impact is difficult. The dengue hemorrhagic fever disturbs the daily activities of people and their family income. They also affect the economic condition of immediate family members, as well as other relatives (Sornmani et al, 1994). Dengue fever considerably affects the population of the plagued area socially and economically (Cattand, 2006). From 1996 to 2005, the World Health Organization reported the numbers of dengue cases increased from 0.4 to 1.3 million. The main factor preventing the understanding of dengue fever is misdiagnoses, which are significantly increasing dengue vectors annually (Suaya et al, 2007).

The negative perceptions of people were considered a major constraint in controlling dengue fever. These behaviors included lack of inclination to keep water clean and covered and keep old tires or other discard things away from home. The health department noticed that the lack of adoption of these behaviors has been a basic barrier in dengue control (Smith, 2012). People were fully aware about mosquito breeding places, yet their behavior was not consistent. They left water containers uncovered, which provides suitable environment to dengue population. The positive control over dengue mosquitoes depended on each member of the community. According to much research, control activities on household have shown poor performance. During dengue outbreak, the community participation became difficult to control (Winch et al, 2002). There were many challenges to community participation in the form of social, financial, political, and other obstacles which affected the skill and capacity of community members in dengue control (Manderson, 1992)

Outstandingly, although there have been large numbers of dengue victims, there has been hardly any economic or social impact of dengue. Although the impacts of dengue have been low, it is essential for policy makers to allocate resources to the research and control of dengue. The incidence rate of dengue fever was 12\% in 1995 and 35\% in 1997(Kouri, 1998 \& Guzmán et al, 1999). There are various factors which increase the breeding of dengue, including lack of diagnostics, ineffective prevention programs, and poor surveillance systems. In Latin America, contributing factors include population growth, which promote global warming and also facilitates vector borne diseases. Insufficient urban planning in Latin America increased the chances of dengue vectors because of garbage and poor cleaning practices (Pan American Health Organization, 2005). Another cause of dengue epidemic is air travel, which transmits dengue mosquitoes from infected areas to other regions (Schneider \& Droll, 2001). Other causes significantly influencing the degree to which dengue spreads are socio-economic status and poor sanitation systems. Currently, negative human activities and social inequalities favor the emergence of dengue. The decline of public health departments also increases the chance of dengue epidemics. Latin American countries and their health departments have prioritized the identification of preventive measures to control dengue 
outbreak because of economic constraints (Pan American Health Organization. 2005 and Kouri et al, 1986).

The economic impact of dengue is difficult to calculate due to the unpredictability of the number of dengue cases in a given year. For example, by applying the human capital method and non- agedependent indicative rate, the cost of the 2000 epidemic was US $\$ 64$ million, and the 2005 epidemic cost $\$ 160$ million. The distribution cost was $\$ 415$ million from 2000-2009 without control costs. By using the friction cost method, the means of 5th and 95th percentiles of $\$ 236$ and $\$ 504$ million was $\$ 351$ million. The control cost was $\$ 500$ million. Therefore, from 2000 to 2009 the total economic costs by using human capital method and friction cost method were $\$ 0.91$ billion and $\$ 0.85$ billion respectively. Those estimates increased to $\$ 1.06$ billion for the human capital method and $\$ 1.15$ billion for the friction cost method when age-dependent symptomatic rates are used. Ambulatory cases had higher cost by age dependent symptomatic rates. By using constant symptomatic rates, the largest share of cost recorded was for hospitalized cases (Lum, 2008).

\section{Dengue Prevention and Health Belief Model}

The control of dengue fever is possible through health behavior theory. The significance of this theory is to develop a theoretical framework, and to design health education and behavior intervention change. It calls for supplying education, equipment, and communication to control dengue mosquitoes (Glanz etal, 1997). Therefore, the prevention of dengue fever may make use of health behavior theory. Another approach which establishes the back bone and theoretical approach to dengue prevention is HBM (health belief model) (Strecher and Rosentock, 1997).

The most important components of HBM are perceived severity, susceptibility, cues-to-action, perceived benefits, perceived barriers, and self-efficacy. The perceived severity is the association of contracting the disease with negative health consequences, while perceived susceptibility is a belief of a person regarding the possibility of contracting a disease. These two principles form the perceived risk to health. The cues-to-action construct refers to anything that may improve awareness or increase interest in performing the activities necessary to control, prevent, treat, or improve health related issues. The cues-to action could be a promotion in the form of a message on a poster or pamphlet, placard or radio campaign. Mass and print media play a vital role in awareness regarding health education. The beliefs of the masses in the value of adhering to health-related procedures to control the disease are known as perceived benefits. Self-efficacy refers to the confidence of people in taking health-related action. Bandura developed the social learning or cognitive theory, but it was also quickly added to HBM. HBM is a step-by-step approach to control dengue vectors, and also promote conviction among people to clean up dengue breeding sites on a weekly basis. Similarly, perceived barriers refer to mental blocks and perceived costs which prevent people from taking action to control disease. If the perceived benefits are outweighed by the perceived costs, the suggested activity will not be enacted (Strecher and Rosentock, 1997).

\section{MATERIALS AND METHODS}

This research study was carried out in the Swat District, Khyber Pakhtunkhwa Province, Pakistan. Persons affected from dengue fever in Tahir Abad, Angaro Dheri, Usman Abad and Banr were the potential respondents for this study because urban and semi-urban areas in these regions were badly affected by dengue outbreak. Therefore, a pilot study was conducted by the researcher to determine 
the number of dengue cases in the study area, according to which a total of 4440 persons were affected from dengue fever. For a population size of 4440, a sample size of 354 respondents was selected through criterion devised by Sekaran (2003). Cronbach's alpha test was applied to determine the inside consistency of the rudiments/instrument that represent the index. Alpha measures the degree of elements comprising the scale "hang together." The range of alpha value is from zero to one. So, the value of alpha coefficient is 0.7 which indicates the reliability and validity of the instrument (Nachmias, 1992).

A conceptual framework was devised as shown in the Table 1 and the interview schedule and face to face interview were used as tools for data collection. The dependent variable (practices for control) was indexed and cross tabulated with the independent variable (barriers to prevention) to measure the association. To test the relationship between the two variables the Chi Square Test was used. The mathematical form of Chi Square test is as under (Taj, 1978).

$$
x^{2}=\sum_{i=1}^{r} \sum_{j=1}^{c} \frac{\left(O_{i j}-e_{i j}\right)^{2}}{e_{i j}}
$$

Table -1: Conceptual framework

\begin{tabular}{|l|c|}
\hline Independent variable & Dependent variable \\
\hline Barriers to prevention & Practices for control \\
\hline
\end{tabular}

The basic principles for Chi- Square Test are given below

1. The subjects for each group are randomly and independently selected.

2. Selection of respondents without replacement.

3. Sample size must fairly be large (at least 10) and no expected frequency is less than five in cells of the contingency table.

If the last principle has been violated in data, then the Fisher Exact Test was used instead of simple Chi- Square Test. The mathematical form of the Fisher Exact Test as,
Fisher Exact Test $=$

$$
\underline{(a+b) !(c+d) !(a+c) !(b+d) !}
$$
$N ! a ! b ! c ! d !$

Where a, b, c, d and " $n$ " represented the observed numbers in four cells of the contingency table and the total number of observations, respectively.

\section{RESULTS AND DISCUSSION}

\subsection{Frequency and Percentage Distributions Regarding Barriers to Dengue Prevention}

The perception of respondents about barriers and constrains in dengue prevention in the study area is given in Table 2 . The study shows that a majority $(92.4 \%)$ of respondents identified their residential area as a breeding place for dengue mosquitoes. The masses were not participating at Mahallah level to clean and remove standing water, discard broken items, or other breeding sites, and never checked/examined water containers. Similarly, high population density also provides suitable environment for dengue population in the studied area. Moreover, a high proportion (73\%) of respondents had access to medical facilities and treatment. The result makes it evident that the 
people had no problem regarding treatment and medical facilities. However, they got treatment from private health units through self-support, due to low attention of government agencies. Most $(78.2 \%)$ of the respondents stated that government was not active in eradication of dengue vectors. Moreover, 79.7 percent of respondents pointed out that they had not followed the advice of government agencies and NGOs for prevention or control of dengue. Therefore, the masses faced many barriers in dengue prevention in the form of political rigidity, misunderstanding, and lack of coordination among various agencies. The government agencies were passive in giving proper attention in dengue eradication and had extended insufficient advice to people regarding dengue prevention and treatment. These results were supported by Claro et al. (2006), who found that lack of coordination between government agencies, such as municipal health departments, and local community, increased the population of dengue mosquitoes. Likewise, $50.8 \%$ of respondents reported that insecticides for controlling dengue mosquitoes were available in the market, but due to high treatment cost they were unable to use them. In addition, $58.8 \%$ of respondents identified that it was not easy to remove and fill standing water because of high rainfall. This result was supported by Lennon (2004), who found that prices of insecticides and unavailability of masses to eradicate dengue vector were causing dengue spread. A high proportion (76.6\%) of respondents used bed nets for protecting themselves against mosquitoes while 60.2 percent did not use mosquito repellents to protect themselves from dengue attack. Moreover, high proportion (61.6\%) of respondents identified that they felt it inconvenient to sleep in bed nets during dengue fever. Although, most of the masses used mosquito nets as protective measure, they felt uncomfortable due to sever muscular pain and high temperature.

Table -2: Frequencies and percentage allocation of respondents about their perception of barriers in dengue prevention $(N=354)$

\begin{tabular}{|l|l|l|l|}
\hline Statements & Yes & No & Don't know \\
\hline $\begin{array}{l}\text { Your residential area has sufficient areas where } \\
\text { mosquitoes can breed. }\end{array}$ & $327(92.4)$ & $27(7.6)$ & 00 \\
\hline $\begin{array}{l}\text { You have access to medical facilities in case of } \\
\text { dengue. }\end{array}$ & $261(73.7)$ & $93(26.3)$ & 00 \\
\hline $\begin{array}{l}\text { Government agencies are active in eradication of } \\
\text { mosquitoes. }\end{array}$ & $74(20.9)$ & $277(78.2)$ & $3(.8)$ \\
\hline $\begin{array}{l}\text { Insecticides for controlling dengue mosquitoes are } \\
\text { available in market. }\end{array}$ & $180(50.8)$ & $86(24.3)$ & $88(24.9)$ \\
\hline $\begin{array}{l}\text { You use bed net for protecting yourself against } \\
\text { mosquitoes. }\end{array}$ & $271(76.6)$ & $83(23.4)$ & 00 \\
\hline $\begin{array}{l}\text { You use mosquito repellent for preventing dengue } \\
\text { attack. }\end{array}$ & $140(39.5)$ & $213(60.2)$ & $1(.3)$ \\
\hline You follow the advices/ instructions given by & $71(20.1)$ & $282(79.7)$ & $1(.3)$ \\
\hline It is not easy to fill in all stagnate water places. & $208(58.8)$ & $145(41.0)$ & $1(.3)$ \\
\hline It is inconvenient sleep in bed nets. & $218(61.6)$ & $92(26.0)$ & $44(12.4)$ \\
\hline
\end{tabular}

* Data in table show frequencies \& parenthesis show the percentages.

\subsection{Association Between Barriers to Prevention and Practices for Control}

Dengue fever is a universal problem, especially in developing countries like Pakistan. The prevention of dengue vectors is a difficult task because there are many barriers in dengue control, 
such as breeding sites in living areas, poor attention of government agencies, and lack of knowledge about protective measures. To ascertain the relationship between barriers to prevention and practices for control, the perception of barriers to prevention was limited to a few statements as mentioned in Table-3 and discusses below.

The results show that a significant $(\mathrm{p}=0.034)$ association was found between access to medical facilities and practices for control. Therefore, those people who had good access to medical facilities and treatment during dengue epidemic were safer from dengue fever. Similarly, a significant relationship was found between efforts from government agencies to eradicate dengue mosquito breeding sites, and practices for control $(\mathrm{p}=0.005)$. Similarly, following instructions from the government and NGOs, and practices for control also had a significant correlation $(p=0.008)$. It is evident from these findings that dengue can be controlled through mutual coordination of government agencies and citizens. If the government agencies are active and give advice and instruction to people about dengue fever, then the masses can follow good practices for dengue control. These results are supported by Claro et al. (2006); they found that lack of coordination between government agencies like health and sanitation departments and local communities accelerated dengue outbreak. Moreover, a significant $(p=0.028)$ association was found between use of insecticides and practices for control. Similarly, use of bed nets against dengue mosquitoes and practices for dengue control were also significant $(p=0.000)$ in association. Therefore, the results make it evident that those having knowledge about use of bed net and insecticides followed good practices for dengue control. Furthermore, a highly significant $(p=0.000)$ negative correlation was found between inconvenient sleep in bed nets and practices for control. The result shows that if people felt it inconvenient to sleep in bed net, they may eventually have low practices for control. Abvia et al (2012) supported the conclusion that those people who had knowledge about the use of bed nets against dengue mosquitoes followed good practices for dengue control. On the other hand, a non-significant association $(p=0.234)$ was found between residential area, where dengue mosquitoes could breed, and practices for control. Similarly, the relationship between use of mosquito repellent and practices for control were found to be nonsignificant $(\mathrm{p}=0.492)$. Likewise, a non-significant $(\mathrm{p}=0.059)$ association was established between filled stagnant water and practices for control.

Table -3: Association between barriers to prevention in dengue fever and practices for control $(N=354)$

\begin{tabular}{|c|c|c|c|c|c|}
\hline \multirow{2}{*}{$\begin{array}{l}\text { Barriers } \\
\text { controlling in } \\
\text { Fever }\end{array}$} & \multirow[t]{2}{*}{ Perception } & \multicolumn{2}{|c|}{ Practices for control } & \multirow[t]{2}{*}{ Total } & \multirow{2}{*}{$\begin{array}{l}\text { Chi-Square } \\
(P=\text { Value })\end{array}$} \\
\hline & & Yes & No & & \\
\hline \multirow{3}{*}{$\begin{array}{l}\text { Your residential area } \\
\text { has sufficient areas } \\
\text { where mosquitoes can } \\
\text { breed. }\end{array}$} & Yes & $279(78.8)$ & $48(13.6)$ & $327(92.4)$ & \multirow{3}{*}{$\begin{array}{l}\mid \mathcal{X}^{2}=1.08 \\
7(0.234)\end{array}$} \\
\hline & No & $25(7.1)$ & $2(0.6)$ & $27(7.6)$ & \\
\hline & Don't know & $0(0)$ & $0(0)$ & $0(0)$ & \\
\hline \multirow{3}{*}{$\begin{array}{l}\text { You have access to } \\
\text { medical facilities in } \\
\text { case of dengue. }\end{array}$} & Yes & $230(65.0)$ & $31(8.8)$ & $261(73.7)$ & \multirow{3}{*}{$\begin{array}{l}\| \mathcal{H}^{2}=4.13 \\
5(0.034)\end{array}$} \\
\hline & No & $74(20.9)$ & $19(5.4)$ & $93(26.3)$ & \\
\hline & Don't know & $0(0)$ & $0(0)$ & $0(0.0)$ & \\
\hline \multirow{3}{*}{$\begin{array}{l}\text { Government agencies } \\
\text { are active in eradication } \\
\text { of mosquitoes. }\end{array}$} & Yes & $72(20.0)$ & $2(0.6)$ & $74(20.6)$ & \multirow{3}{*}{$\begin{array}{l}\| \mathcal{H}^{2}=10.78 \\
(0.005)\end{array}$} \\
\hline & No & $230(65.0)$ & $47(13.3)$ & $277(78.2)$ & \\
\hline & Don't know & $2(0.6)$ & $1(0.3)$ & $3(.8)$ & \\
\hline
\end{tabular}




\begin{tabular}{|c|c|c|c|c|c|}
\hline \multirow{3}{*}{$\begin{array}{l}\text { Insecticides for } \\
\text { controlling dengue } \\
\text { mosquitoes are } \\
\text { available in market. }\end{array}$} & Yes & $160(45.2)$ & $20(5.6)$ & $180(50.8)$ & \multirow{3}{*}{$\begin{array}{l}\| \mathcal{H}^{2}=7.159 \\
(0.028)\end{array}$} \\
\hline & No & $76(21.5)$ & $10(2.8)$ & $86(24.3)$ & \\
\hline & Don't know & $68(19.2)$ & $20(5.6)$ & $88(24.9)$ & \\
\hline \multirow{3}{*}{$\begin{array}{l}\text { You use bed net for } \\
\text { protecting yourself } \\
\text { against mosquitoes. }\end{array}$} & Yes & $248(70.1)$ & $23(6.5)$ & $271(76.6)$ & \multirow{3}{*}{$\begin{array}{c}\| \mathcal{X}^{2}=30.22 \\
(0.000)\end{array}$} \\
\hline & No & $56(15.8)$ & $27(7.6)$ & $83(23.4)$ & \\
\hline & Don't know & $0(0.0)$ & $0(0.0)$ & $0(0.0)$ & \\
\hline \multirow{3}{*}{$\begin{array}{l}\text { You use mosquito } \\
\text { repellent for preventing } \\
\text { dengue attack. }\end{array}$} & Yes & $122(34.5)$ & $18(5.1)$ & $140(39.5)$ & \multirow{3}{*}{$\begin{array}{l}\| \mathcal{H}^{2}=0.492 \\
\quad(0.782)\end{array}$} \\
\hline & No & $181(51.1)$ & $32(9.0)$ & $213(60.2)$ & \\
\hline & Don't know & $1(0.3)$ & $0(0.0)$ & $1(0.3)$ & \\
\hline \multirow{3}{*}{$\begin{array}{l}\text { You follow the } \\
\text { advices/instructions } \\
\text { given by Government } \\
\text { agencies/ NGO for } \\
\text { prevention of control. }\end{array}$} & Yes & $69(19.5)$ & $2(0.6)$ & $71(20.1)$ & \multirow{3}{*}{$\begin{array}{l}\mid \mathcal{H}^{2}=9.60 \\
0(0.008)\end{array}$} \\
\hline & No & $234(66.1)$ & $48(13.8)$ & $282(79.7)$ & \\
\hline & Don't know & $1(0.3)$ & $0(0.0)$ & $1(0.3)$ & \\
\hline \multirow{3}{*}{$\begin{array}{l}\text { It is not easy to fill in } \\
\text { all stagnate water } \\
\text { places. }\end{array}$} & Yes & $171(48.3)$ & $37(10.5)$ & $208(58.8)$ & \multirow{3}{*}{$\begin{array}{l}\| \mathcal{X}^{2}=5.68 \\
(0.059)\end{array}$} \\
\hline & No & $132(37.3)$ & $13(3.7)$ & $145(41.0)$ & \\
\hline & Don't know & $1(0.3)$ & $0(0.0)$ & $1(0.3)$ & \\
\hline \multirow{3}{*}{$\begin{array}{l}\text { It is inconvenient sleep } \\
\text { in bed nets. }\end{array}$} & Yes & $183(51.7)$ & $35(9.9)$ & $218(61.6)$ & \multirow{3}{*}{$\begin{array}{l}\| \mathcal{H}^{2}=20.19 \\
(0.000)\end{array}$} \\
\hline & No & $90(25.4)$ & $2(0.6)$ & $92(26.0)$ & \\
\hline & Don't know & $31(8.8)$ & $13(3.7)$ & $44(12.4)$ & \\
\hline
\end{tabular}

*Number in table represent frequencies and number in parenthesis represent percentage proportion of respondents and in the last columns number in the parenthesis represent $\mathrm{P}=$ Value

\section{CONCLUSION AND RECOMMENDATIONS}

The root causes and barriers regarding dengue control were congested streets and houses, population, adequate mosquito breeding sites, and a passive role of government to inform or mobilize the citizens. A large number of patients got treatment and guidelines from local medical practitioners because of low attention of the health department and also limited isolated wards for dengue infected persons. There was a political interference among government workers in communities, due to which government showed passive role in dengue prevention. Similarly, due to rainy/monsoon seasons, a lack of unity was observed among citizens to remove the dengue breeding sites and standing water. However, the people were fully aware about the use of bed nets, although they were found to be inconvenient to sleep in during the times in which dengue fever was spreading, due to high temperature, and bone and muscular pains. Mosquito repellents and insecticides were not commonly used, due to high market price during dengue epidemic. It is also acknowledged that those people who had access to treatment, followed advice and instruction, and used insecticides and mosquito nets were safer from dengue than those who did not. The study suggested that government should play a neutral role, and also pay special attention to controlling mosquito breeding and larva in the most vulnerable areas by providing urgent care services, medicines, chemicals, mosquito repellants, and bed nets free of cost or at a controlled price. 


\section{REFERENCES}

Abvia, R.J.k., F.K.J. Acian., A. L .Arbois., V. C. M. Baluran., P.A. H. Becoy, \& S .Ruz. 2012. Level of Awareness towards Dengue among the Residents of Barangay Kauswagan. Nursing Research Journal, 4, 47-64.

Cattand, P. 2006. Tropical Diseases Lacking Adequate Control Measures. New York., NY, Oxford University press 2: 451-466.

Claro, L. B. L., H. Kawa., L. T. Cavalini and M. L. G. Rosa. 2006. Community Participation in Dengue Control in Brazil. Dengue Bulletin, 30, 214-222.

Glanz K. Lewis F.M. \& Rimer B.K.1997. Linking theory research and practice. In: K. Glanz, F.M. Lewis and B.K. Rimer Eds. Health behavior and health education: theory, research and practice. 2nd ed. San Francisco: Jossey-Bass, 19-40.

Gubler, D.J. 2010. Dengue Viral Infections. Mahy BWJ, Van Regenmortel MHV. Desk Encyclopedia of Human \& Medical Virology, Boston Academic Press.

Guzmán MG, Kouri G, Bravo JR.1999. La emergencia de la fiebre hemorrágica del dengue en las Américas. Reemergencia del dengue. Rev Cubana Med Trop, 51,5-13.

Guzman, M. G. 2002. Effect of Age on Outcome at Secondary Dengue 2 Infections. International journal of infectious Diseases, 6(2), 118-124

Kouri G, Guzman MG, Bravo J.1986. Hemorrhagic dengue in Cuba: history of an epidemic. Bull Pan Am Health Organ ,20, 24-30.

Kouri G, Guzmán MG, Valdés L, Carbonell I, Rosario \& Vázquez S. 1998. Reemergence of dengue in Cuba: a 1997 epidemic in Santiago de Cuba. Emerg Infect Dis, 4, 89-92.

Lennon, J. L, 2004.Students' Perceptions about Mosquito Larval Control in a Dengue-Endemic. Dengue Bulletin, 28,196-206

Lum LC, Suaya JA, Tan LH, Sah BK \& Shepard DS.2008. Quality of life of dengue patients. Am J Trop Med Hyg 78: 862-867

Manderson, L. 1992. Community Participation and Malaria Control in Southeast Asia. Southeast Asian Journal of Tropical Medicine \& Public Health, 23(1), 9-17.

National Institute of Health and World Health Organization. 2013. Weekly Epidemiological Bulletin Islamabad Pakistan, 4(44), 1-7.

Pan American Health Organization. 2005: number of reported cases of dengue and dengue hemorrhagic fever (DHF), region of the Americas (by country and subregion). http://www.paho.org/English/AD/DPC/CD/dengue-cases-2005.htm (accessed on Aug/2006).

Pan American Health Organization.1994. Dengue \& Dengue Hemorrhagic Fever in the Americas: Guidelines for Prevention \& Control. Washington, DC: PAHO Sci Publ, 548, 370 .

Schneider J, Droll D. A timeline for dengue in the Americas to December 31, 2000 and noted first occurrences. http://www.paho.org/English/HCP/HCT/dengue_timeline.xls (accessed on Jun/2001).

Sekaran, U. 2003. Research Methods for Business. USA, Hermitage Publishing Services.

Smith, V. 2012. A Qualitative Analysis: Using the Health Belief Model to Explain Dengue fever in two Communities in Trinidad \& Tobago. Journal of the Department of Behavioral Sciences, 2(1), 90-101.

Sornmani, S., K. Okanurak \& K. Indaratna. 1994. Social \& Economic Impact of Dengue Hemorrhagic Fever in Thailand. Economic Perspective of DHF, 66-81. 
Strecher V.J. and Rosentock I.M.1997. The health belief model. In: K. Glanz, F.M. Lewis, and B.K. Rimer. Eds. Health behavior and health education: theory, research and practice. 2nd Ed. San Francisco: Jossey- Bass, 41-59.

Suaya, J. A., D. S. Shepard \& M. E. Beaty. 2007. Dengue Burden of Diseases \& Costs of Illness. World Health Organization, Special Programme for Research \& Training in Tropical Diseases, 35-49.

Tai, Simon. W. 1978. Social Science Statistics, it Elements \& Applications. California, Goodyear Publishing Company.

Winch, P. J., E, Leontsini., C. J. P. Rigau., M. P. Ruiz., G. G. Clark \& D. J. Gubler. 002. Community-Based Dengue Prevention Programme in Puerto Rico. Impact on Knowledge, Behavior, and Residential Mosquito Infestation. American Journal of Tropical Medicine \& Hygiene, 67, 363-370.

World Health Organization. 1997. Dengue Hemorrhagic Fever. Diagnosis, Treatment, Prevention and Control. 2nd ed. Geneva: Available at: www. World Health Organization. World Health Organization/emc / diseases/ebola / Dengue publication/index.html (accessed 20th December 2013). 